Огляди літератури, оригінальні дослідження, погляд на проблему, ювілеї

УДК 612.015.11/32-02:616.748-018.6-06:616.005.4]-092.9

DOI 10.11603/1811-2471.2018.v0.i3.9318

\title{
ДИНАМІКА ПОКАЗНИКІВ ПЕРЕКИСНОГО ОКИСНЕННЯ ЛІПІДІВ ТА АНТИОКСИДАНТНОГО ЗАХИСТУ В М'ЯЗОВІЙ ТКАНИНІ ЗАДНІХ КІНЦІВОК ЩУРІВ ПРИ РОЗВИТКУ ІШЕМІЧНО-РЕПЕРФУЗІЙОГО СИНДРОМУ (ЕКСПЕРИМЕНТАЛЬНЕ ДОСЛІДЖЕННЯ)
}

\section{ДВНЗ «Тернопільський державний медичний університет імені І. Я. Горбачевського мОз України»}

РЕзЮМЕ. Гостра ішемія кінцівки виникає в результаті раптового зниження її перфузії, що зазвичай виникає при обтурації просвіту великих артерій внаслідок гострого тромбозу чи емболії або порушення прохідності судин, спричиненого їх травмами чи стисненням (включаючи накладання кровоспинних турнікетів). У разі відновлення кровопостачання раніше ішемізованих тканин виникає ішемічно-реперфузійний синдром, при якому однією 3 основних патогенетичних ланок альтерації тканин $€$ активація перекисного окиснення ліпідів.

Мета дослідження - провести порівняльний аналіз показників перекисного окиснення ліпідів та антиоксидантного захисту в гомогенаті м'язової тканини задніх кінцівок щурів у різні періоди розвитку ішемічнореперфузійного синдрому.

Матеріал і методи. Проведено визначення вмісту дієнових кон'югат, трієнових кон'югат, ТБК-активних продуктів, супероксиддисмутази та каталази в гомогенаті м'язової тканини 30 щурів за умов експериментальної гострої ішемії. Гостру ішемію викликали шляхом накладення гумових джгутів SWAT (Stretch-Wrap-And-Tuck) на задні кінцівки тварин тривалістю 2 год. Кількісні показники обробляли статистично.

Результати. Експериментально встановлено, що максимальне зростання вмісту дієнових та трієнових кон'югат у пошкодженій м'язовій тканині тварин відбувалося в ранньому постішемічному періоді на 2-гу годину реперфузії зі зниженням на 1-шу та 7-му добу та поверненням до рівня показників контрольної групи в пізньому постішемічному періоді, на 14-ту добу. Зростання вмісту ТБК-активних продуктів у м'язовій тканині відбувалось у перших трьох групах щурів і досягло максимуму в 3-ій групі (реперфузія 1 доба), після чого знижувалось у пізньому реперфузійному періоді, досягши в останній групі значень, близьких до показників контрольної групи.

Активність супероксиддисмутази і каталази в ранньому постішемічному періоді поступово зростала і досягла максимуму на 7-му добу ішемічно-реперфузійного синдрому, після чого, на 14-ту добу, показники повернулись до рівня значень групи контролю. Сильний позитивний кореляційний зв'язок між показниками вмісту супероксиддисмутази і каталази $(+0,99)$ вказував на аналогічну динаміку змін зазначених показників. В усіх експериментальних групах щурів у м'язовому гомогенаті відмічалось зниження антиоксидантно-прооксидантного індексу, яке було найбільш вираженим на 1-шу добу ішемії-реперфузії.

Висновки. У всіх досліджуваних групах тварин розвивався ішемічно-реперфузійний синдром з активацією перекисного окиснення ліпідів та антиоксидантного захисту. Перекисне окиснення ліпідів наростало в м'язовій тканині, починаючи з 1-ї години реперфузії, і досягало максимуму на 1-шу добу, після чого більшість показників поступово повертались до значень контрольної групи на 7-му та 14-ту доби реперфузії. Активність ферментів антиоксидантного захисту також поступово зростала і досягла максимуму в м'язовій тканині на 7-му добу, а на 14-ту добу відбулось повернення показників антиоксидантного захисту до рівня значень групи контролю. Зростання активності супероксиддисмутази і каталази свідчить про активацію компенсаторних механізмів антиоксидантного захисту в ішемізованій м'язовій тканині, а їх відносно невисоке зростання може вказувати на субкомпенсований рівень розвитку цих механізмів.

Зменшення показника антиоксидантно-прооксидантного індексу в м'язовій тканині було найбільш вираженим на 1-шу добу реперфузії, після чого індекс поступово зростав. Про протилежні тенденції в динаміці змін вмісту про- та антиоксидантів у гомогенаті ішемізованої м'язової тканини свідчить і зворотний кореляційний зв'язок середньої сили між продуктами пОЛ (дієнові та трієнові кон'югати) та ферментами антиоксидантного захисту (супероксиддисмутаза і каталаза).

КЛЮчОВІ СЛОВА: гостра ішемія; м'язова тканина; ішемічно-реперфузійний синдром; перекисне окиснення ліпідів, антиоксидантний захист.

Вступ. Гостра ішемія - раптове зниження перфузії кінцівки, що створює потенційну загрозу її життєздатності. Найчастішими причинами такого стану $\epsilon$ обтурація просвіту великих артерій внаслідок гострого тромбозу чи емболії та порушення прохідності судин, спричинене їх травмами чи стисненням (включаючи накладання кровоспинних турнікетів) $[1,8]$. Частота виникнення гострої ішемії кінцівок складає 140 випадків на 1 млн населення на рік $[2,3]$. У разі відновлення кровопостачання виникає мультифакторне ураження раніше ішемізованих і віддалених від місця ішемії тканин, яке називають ішемічно-реперфузійним синдромом (IPC), що характеризується порушенням клітинного обміну та цілісності клітинних мембран, накопиченням у нефізіологічних концентраціях 
Огляди літератури, оригінальні дослідження, погляд на проблему, ювілеї

продуктів метаболізму, активацією процесів некрозу і апоптозу [4-7]. Зазначені патологічні процеси $\epsilon$ вагомими механізмами альтерації тканин $\mathrm{i}$ виникають унаслідок порушення енергетичного i іонного обміну та збільшення продукції токсичних форм кисню.

Вивченню ролі перекисного окиснення ліпідів (ПОЛ) у патогенезі IPC присвячена значна кількість наукових публікацій [8-12], проте залишається недостатньо вивченою динаміка ПОЛ та антиоксидантного захисту (АОЗ) на місцевому рівні в різні періоди ішемії-реперфузії [13].

Метою роботи було провести порівняльний аналіз показників перекисного окиснення ліпідів та антиоксидантного захисту в гомогенаті м'язової тканини задніх кінцівок щурів у різні періоди розвитку ішемічно-реперфузійного синдрому.

Матеріал і методи дослідження. Проведено визначення вмісту дієнових кон'югатів (ДК), трієнових кон'югатів ТК, ТБК-активних продуктів (ТБК-АП), супероксиддисмутази (СОД) та каталази в гомогенаті ішемізованої м'язової тканини 30 білих щурів за умов експериментальної гострої ішемії.

Гостру ішемію викликали шляхом накладення гумових джгутів SWAT шириною 5-6 мм на задні кінцівки тварин, на рівні пахової складки протягом 2 годин під тіопентал натрієвим знеболюванням. Реперфузійний синдром моделювали шляхом відновлення кровообігу у раніше ішемізованих кінцівках після зняття турнікету. Спостереження за тваринами здійснювали протягом 14 діб.

Під час експерименту тварини були поділені на 5 груп дослідження, по 6 тварин у кожній. У контрольній групі було 5 інтактних тварин. Модель раннього постішемічного періоду була представлена групами тварин із реперфузійними змінами на 1-шу годину, 2-гу годину та 1-шу добу після зняття турнікету, а модель пізнього постішемічного періоду - на 7-му та 14-ти добу після зняття турнікету.
Евтаназію тварин здійснювали шляхом декапітації під тіопентал-натрієвим знеболюванням.

Гомогенат м'язової тканини (10\%) отримували шляхом подрібнення 0,5 г чотириголового м'яза стегна у 4,5 мл фізрозчину з допомогою апарату "Silent Crasher S Homogenizer» з подальшим центрифугуванням протягом 15 хвилин при 3000 об/хв. Надосадову рідину відбирали і використовували для дослідження. Показники ПОЛ визначали у кожній піддослідній групі. Дослідження показників проводили у центральній науковій дослідній лабораторії Тернопільського державного медичного університету імені І. Я. Горбачевського. Визначення ДК, ТК, ТБК-АП, каталазної активності та активності СОД проводилось за загальноприйнятими методиками [14-17]. Антиоксидантно-прооксидантний індекс (АПІ), який належить до чутливих індикаторів антиоксидантного захисту і відображає баланс між прооксидантними і антиоксидантними механізмами, розраховували за формулою: АПI = активність каталази / вміст ТБК-активних продуктів [18].

Статистичну обробку матеріалу проводили з використанням пакета програм "Microsoft Excel" (Microsoft Office 2007). Визначали такі показники: середнє арифметичне (М), середнє квадратичне відхилення (б) і помилку середнього арифметичного (m). Статистичну значущість різниці між середніми арифметичними та відносними величинами за нормального розподілу оцінювали за критерієм Стьюдента-Фішера (t). При порівнянні однотипних груп проводили кореляційний аналіз з урахуванням коефіцієнта кореляції (г) за допомогою методу квадратів Пірсона.

Результати й обговорення. Було проведено вивчення динаміки показників ПОЛ та АОЗ в гомогенаті м'язів ішемізованих кінцівок щурів. Отримані значення ДК, ТК, ТБК-АП, СОД та каталази представлені в таблиці 1.

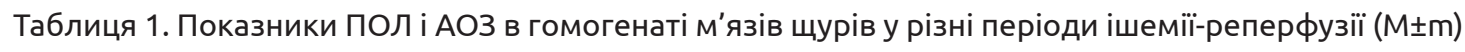

\begin{tabular}{|c|c|c|c|c|c|}
\hline Групи тварин & $\begin{array}{c}\text { Дієнові } \\
\text { кон'югати, } \\
\text { ум.од./г }\end{array}$ & $\begin{array}{c}\text { Трієнові } \\
\text { кон'югати, } \\
\text { ум.од./г }\end{array}$ & $\begin{array}{c}\text { ТБК-активні } \\
\text { продукти, } \\
\text { мкмоль/кг }\end{array}$ & $\begin{array}{c}\text { Супероксид- } \\
\text { дисмутаза, } \\
\text { ум.од. }\end{array}$ & $\begin{array}{c}\text { Каталаза, } \\
\text { кат/кг }\end{array}$ \\
\hline Контрольна група & $0,103 \pm 0,016$ & $0,060 \pm 0,08$ & $5,57 \pm 0,37$ & $68,82 \pm 4,53$ & $43,28 \pm 1,70$ \\
\hline $\begin{array}{l}\text { Реперфузія, } \\
1 \text { година }\end{array}$ & $0,115 \pm 0,012$ & $0,078 \pm 0,011$ & $6,30 \pm 0,26^{*}$ & $70,80 \pm 4,90 *$ & $43,78 \pm 1,85$ \\
\hline $\begin{array}{l}\text { Реперфузія, } \\
2 \text { години }\end{array}$ & $0,133 \pm 0,012^{*}$ & $0,096 \pm 0,022$ & $8,03 \pm 0,16 * / * *$ & $75,34 \pm 4,40 * / * * *$ & $47,40 \pm 1,74 * / * *$ \\
\hline $\begin{array}{l}\text { Реперфузія, } \\
1 \text { доба }\end{array}$ & $0,124 \pm 0,007$ & $0,055 \pm 0,015$ & $9,19 \pm 0,18 * / * * *$ & $77,44 \pm 4,14 * / * * *$ & $49,80 \pm 1,43 * / * *$ \\
\hline $\begin{array}{l}\text { Реперфузія, } \\
7 \text { діб }\end{array}$ & $0,091 \pm 0,009 * * *$ & $0,041 \pm 0,009$ & $8,26 \pm 0,19 * / * *$ & $83,96 \pm 3,51 *$ & $53,54 \pm 1,94 * / * *$ \\
\hline $\begin{array}{l}\text { Реперфузія, } \\
14 \text { діб }\end{array}$ & $0,108 \pm 0,006$ & $0,059 \pm 0,020$ & $7,47 \pm 0,26 * / * *$ & $73,52 \pm 4,07 * / * *$ & $46,52 \pm 2,08 * / * * *$ \\
\hline
\end{tabular}

Примітка. * - Р<0,05 відносно контрольної групи; ** - P<0,05 відносно попередньої групи; *** - P<0,005 відносно попередньої групи. 
Огляди літератури, оригінальні дослідження, погляд на проблему, ювілеї

Дослідження показали, що моделювання IPC супроводжувалося зростанням продуктів ПОЛ у гомогенаті скелетних м'язів експериментальних тварин у ранньому постішемічному періоді (рис. 1). Рівень ДК на 1-шу годину реперфузії зріс на $12,06 \%$, порівняно з групою контролю $(P>0,05)$. На 2-гу годину відмічено статистично значуще (на 29,57 \% вище контрольної групи) зростання рівня ДК $(P<0,05)$, який залишався достатньо високим (на 20,23 \% вище групи контролю) і на 1-шу добу $(P>0,05)$. На 7-му добу постішемічного періоду зафіксовано статистично значуще зменшення зазначеного показника на 26,21 \% відносно попередньої групи $(P<0,005)$, який був на $11,28 \%$ нижчим за показник контрольної групи $(P>0,05)$. На 14-ту добу показник наблизився до значення контрольної групи, лише на 5,06 \% перевищуючи його $(P>0,05)$.

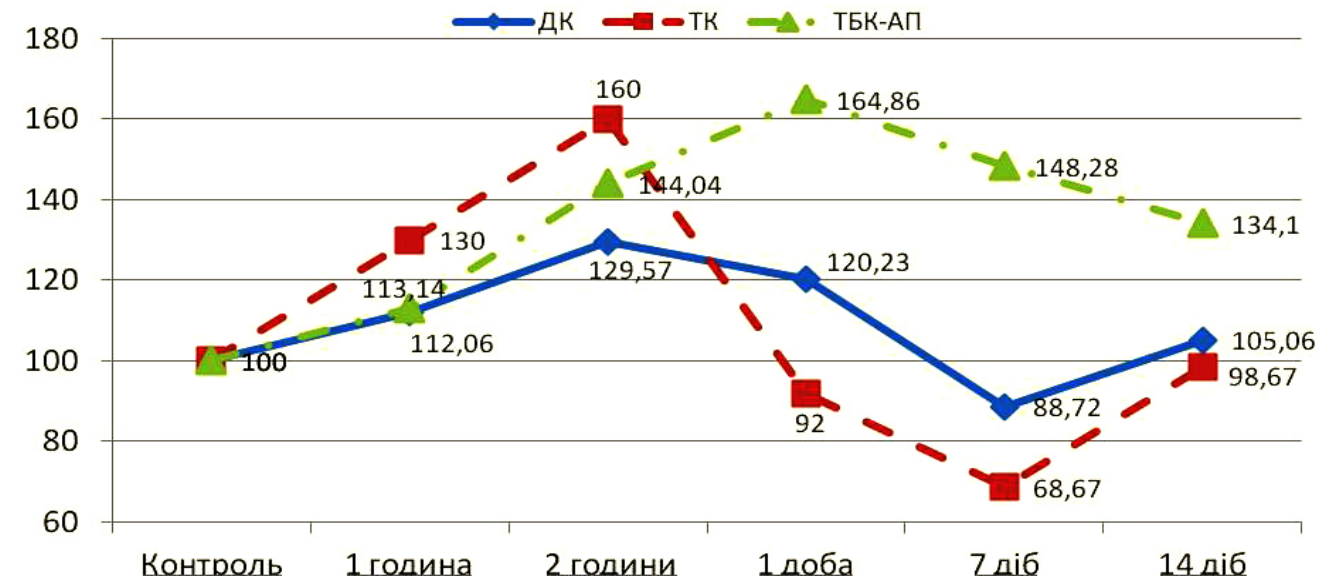

Рис 1. Динаміка показників перекисного окиснення ліпідів (ДК, ТК і ТБК-АП) у гомогенаті м'язової тканини в різні періоди реперфузії (у відсотках стосовно контрольної групи).

Схожу динаміку мали і показники ТK у гомогенаті ішемізованих скелетних м'язів щурів. На 1-шу годину реперфузії вміст ТK зріс на 30,0\% $(P>0,05)$, на 2-гу годину - на 60,0\% відносно групи контролю $(P>0,05)$. Зменшення показника ТК на 42,5 \% відносно попередньої групи зафіксовано на 1-шу добу експерименту (який на 8,0 \% був нижчим за показник контрольної групи, Р>0,05). Мінімального значення показник досяг на 7-му добу експерименту, який виявлявся на $31,33 \%$ нижчим за значення групи контролю $(P>0,05)$. На 14-ту добу вміст ТК не суттєво різнився від значень контрольної групи тварин (був нижчим лише на $1,33 \%)$, проте результати не виявились статистично значущими $(P>0,05)$.

Експериментально встановлено, що максимальне зростання вмісту ДК та ТК у пошкодженій м'язовій тканині тварин відбувається в ранньому постішемічному періоді на 1-шу добу реперфузії зі зниженням чи поверненням до рівня показників контрольної групи тварин у пізньому постішемічному періоді на 7-му та 14-ту доби IPC.

Експериментально виявлено зростання ТБКактивних продуктів ПОЛ у гомогенаті м'язів тварин усіх груп раннього реперфузійного періоду. На 1-шу годину експерименту вміст ТБК-АП зріс на $13,14 \%(P<0,05)$, на 2-гу годину зростання показника досягло 44,04 \% відносно групи контролю $(\mathrm{P}<0,005)$. Максимального значення даний показник досяг у 3-ій групі щурів (реперфузія 1 доба) - на 14,45 \% вище за показник попередньої групи та на 64,86 \% вище за показник групи контролю, що виявилось статистично значущим $(P<0,005)$. На 7-му добу реперфузії спостерігали зменшення вмісту ТБК-АП ПОЛ відносно попередньої групи на $10,06 \%(P<0,05)$. На 14-ту добу цей показник досяг мінімального значення і був на 34,1 \% вищим за контрольний $(P<0,05)$.

Аналізуючи динаміку ТБК-АП ПОЛ в м'язовій тканині ми встановили, що показник наростав у перших двох групах щурів і досяг максиму в 3-ій групі (1 доба), після чого знижувався у тварин в пізньому реперфузійному періоді, досягши в останній групі значень, які незначно перевищували показники контрольної групи $(P<0,05)$.

Дослідження показали, що внаслідок ішемії-реперфузіїу пошкоджених м'язах відбувається помірна активація $\mathrm{AO}$ (рис. 2). У тварин групи раннього постішемічного періоду зафіксовано статистично значуще зростання рівня СОД відносно контрольної групи: на 2,88 \% у тварин 1 групи (реперфузія 1 год) $(P<0,05)$, на 9,47 \% - у щурів 2-ї групи (2 год) $(P<0,0005)$ та на $12,53 \%$ - у тварин 3-ї групи (1 доба) $(\mathrm{P}<0,0005)$. Максимального значення показник СОД досяг у тварин з терміном реперфузії 7 діб, який був на 22,0 \% вищим від рівня контрольної групи $(P<0,05)$ та на 8,42 \% вищим від показника попередньої групи $(P<0,05)$. На 14-ту добу експерименту рівень СОД зменшився і лише на 6,83 \% перевищував значення показника групи контролю $(\mathrm{P}<0,05)$. 
Огляди літератури, оригінальні дослідження, погляд на проблему, ювілеї

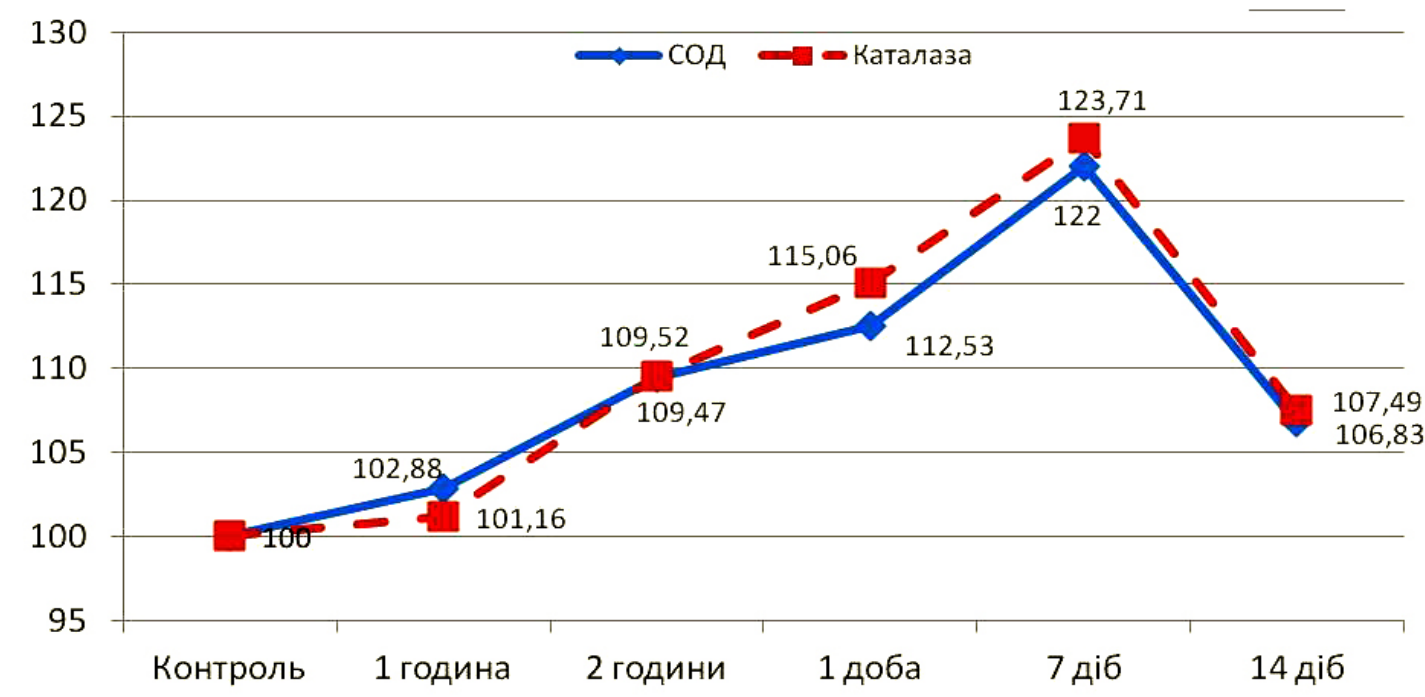

Рис. 2. Динаміка показників антиоксидантного захисту (СОД і каталаз) у гомогенаті м'язової тканини в різні періоди реперфузії (у відсотках стосовно контрольної групи).

Експериментально виявлено помірне статистично значуще підвищення активності каталази у гомогенаті м'язової тканини в усіх групах експериментальних щурів. Якщо в 1-ій групі зростання активності каталази становило лише $1,16 \%$ $(P>0,05)$, то у 2-ій, з терміном реперфузії 2 год, $9,52 \%$ ( $\mathrm{P<0,005).} \mathrm{На} \mathrm{1-шу} \mathrm{добу} \mathrm{показник} \mathrm{продов-}$ жував зростати і був вищим за відповідний показник групи контролю на 15,06 \% (P<0,005). Найвищого значення показник активності каталази досяг у тварин на 7-му добу реперфузії і був на 23,71 \% вищим за відповідний показник групи контролю $(\mathrm{P}<0,005)$. На 14-ту добу експерименту активність даного ферменту зменшилась і лише на 7,49 \% перевищувала показник контрольної групи $(P<0,05)$.
Отже, динаміка зміни вмісту каталази в значній мірі відображає динаміку СОД, досягаючи максимуму на 7-му добу IPC.

Значення показника антиоксидантно-прооксидантного індексу у усіх експериментальних групах тварин виявилося статистично достовірно нижчим, ніж у контрольній групі (рис. 3). У тварин з реперфузією на 1-шу добу він досяг мінімального значення $(5,42$ ум. од.) і був на $31,61 \%$ нижчим від показника контрольної групи $(P<0,05)$. На 7-му добу показник АПІ зріс на 19,81 \% відносно попередньої групи $(\mathrm{P}<0,05)$, проте залишався нижчим за показник групи контролю на $18,06 \%(P<0,05)$. У тварин з реперфузією 14 діб даний показник був на $21,18 \%$ нижчим за аналогічний контрольної групи $(P<0,05)$.

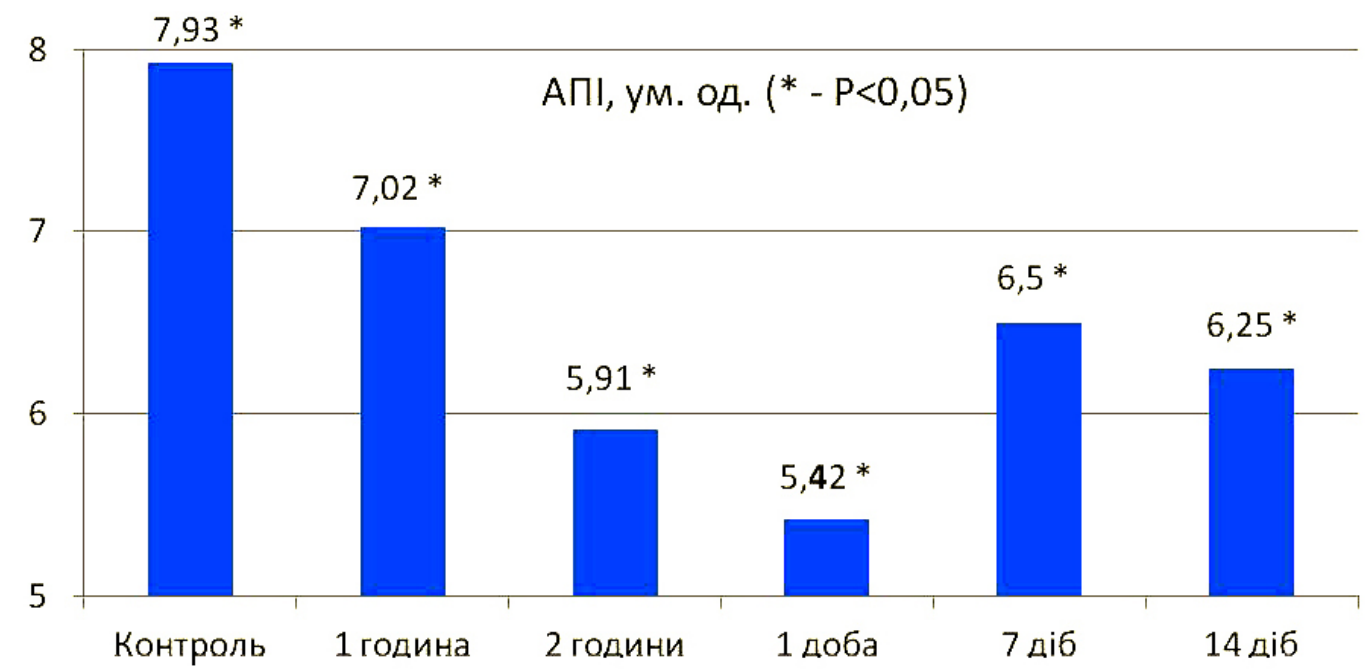

Рис. 3. Показники антиоксидантно-прооксидантного індексу (в ум. од.) в гомогенаті м'язів ішемізованої кінцівки щурів у різні періоди ішемії-реперфузії. 
Огляди літератури, оригінальні дослідження, погляд на проблему, ювілеї

У результаті експерименту відбулося зниження АПІ в усіх експериментальних групах щурів, яке було найбільш вираженим на 1-шу добу ішемії-реперфузії.

Проведено кореляційний аналіз між показниками ПОЛ та АОЗ в гомогенаті м'язової тканини (табл. 2), в результаті якого виявлено прямий сильний кореляційний зв'язок між ДК і ТК $(+0,79)$, між ТБК-АП і каталазою $(+0,75)$ та між СОД і каталазою $(+0,99)$, а також прямий кореляційний зв'язок середньої сили між ТБК-АП і СОД $(+0,66)$. Між ДК і ТБК-АП $(-0,39)$, ДК і СОД $(-0,54)$, ДК і каталазою $(-0,49)$, ТК і СОД $(-0,66)$ та ТК і каталазою $(-0,69)$ мала місце негативна кореляція середньої сили, а між ТК і ТБК-АП негативна кореляція була слабкою $(-0,19)$.

Таблиця 2. Кореляційний аналіз показників перекисного окиснення ліпідів та антиоксидантного захисту в гомогенаті м'язової тканини щурів

\begin{tabular}{|l|c|c|c|c|c|}
\hline & ДК & ТК & ТБК-АП & СОД & Каталаза \\
\hline ДК & - & $+0,79$ & $-0,39$ & $-0,54$ & $-0,49$ \\
\hline ТК & $+0,79$ & - & $-0,19$ & $-0,66$ & $-0,69$ \\
\hline ТБК-АП & $-0,39$ & $-0,19$ & - & $+0,66$ & $+0,75$ \\
\hline СОД & $-0,54$ & $-0,66$ & $+0,66$ & - & $+0,99$ \\
\hline Каталаза & $-0,49$ & $-0,69$ & $+0,75$ & $+0,99$ & - \\
\hline
\end{tabular}

Висновки. У ранньому постішемічному періоді наростання вмісту продуктів ПОЛ (ДК, ТК та ТБК-АП) в гомогенаті ушкодженої м'язової тканини відбувалося уже з першої години реперфузії. Максимального значення показники ПОЛ досягли на 2-гу годину (ДК - 0,133 ум.од./г та ТБК-АП 9,19 ммоль/Кг) та 1-шу добу (ТК - 0,096 ум.од./г). Після досягнення пікових значень відбувалося поступове зниження вмісту вказаних продуктів у м'язовій тканині (на 1-шу та 7-му добу), а на 14-ту добу вміст продуктів ПОЛ в гомогенаті наблизився до рівня показників контрольної групи.

При моделюванні ішемії-реперфузії в м'язовому гомогенаті відмічалось помірне (яке не перевищувало 25 \% відносно групи контролю) наростання активності ферментів АОЗ (СОД і каталази) з максимумом на 7-му добу реперфузії $(\mathrm{P}<0,05)$, після чого на 14-ту добу показники зменшувались до рівня показників групи контролю ( $<<0,05)$. Таким чином, помірне зростання активності СОД і каталази при IPC з максимум на 7-му добу реперфузії свідчить про активацію компенсаторних механізмів АОЗ в ішемізованій м'язовій тканині, а відносно невисоке їх зростання та досягнення максимальної активності аж на 7-му добу IPC може вказувати на субкомпенсований рівень розвитку цих механізмів.
Відсутність зниження показників СОД і каталази нижче показників групи контролю свідчить, на нашу думку, про відсутність декомпенсованого порушення АОЗ при реперфузії після короткотривалої (2-годинної) ішемії. Динаміка змін показників СОД і каталази була синхронною, про що свідчить прямий сильний кореляційний зв'язок між ними $(+0,99)$.

У ранньому реперфузійному періоді відмічалось статистично значуще зменшення показника АПІ, яке досягло мінімального значення на 1-шу добу реперфузії (на 31,61 \% нижче групи контролю, $\mathrm{P}<0,05)$, що вказує на наростання в м'язовій тканині у цей період дисбалансу між ПОЛ та АОЗ на користь пероксидації. У пізньому реперфузійному періоді відбулось зростання показника АПІ, проте він не досяг початкового рівня, що свідчить про поступове відновлення балансу в системі прооксидантів та антиоксидантів, яке ще не завершується повністю на 14-ий день реперфузії.

Про протилежні тенденції в динаміці змін вмісту про- та антиоксидантів в ішемізованій м'язовій тканині свідчить і зворотний кореляційний зв'язок середньої сили між ДК і СОД $(-0,54)$, ДК і каталазою $(-0,49)$, ТК і СОД $(-0,66)$ та ТК і каталазою $(-0,69)$.

\section{ЛІТЕРАТУРА}

1. Покровский А. В. Национальные рекомендации по ведению пациентов с заболеваниями артерий нижних конечностей / А. В. Покровский, Л. А. Бокерия. - М., 2013. -67 c.

2. Губка В. О. Результати лікування хворих із гострою артеріальною ішемією кінцівок / В. О. Губка, І. А. Коноваленко, О. В. Суздаленко // Патологія. - 2015. № 2 (34). - C. 55-58.

3. Гавриленко А. В. Состояние микроциркуляции при реперфузионном синдроме после реконструктивных операций на сосудах нижних конечностей / А. В. Гавриленко, Е. Д. Шабалтас // Хирургия. - 2003. № $2-$ С. 62.

4. Геник С. М. Реперфузійний синдром після реваскуляризації ішемії нижніх кінцівок / С. М. Геник, А. В. Симчич // Серце і судини. - 2016. - № 3. - С. 104-108. 
Огляди літератури, оригінальні дослідження, погляд на проблему, ювілеї

5. Safe tourniquet use: a review of the evidence / P. G. Fitzgibbons, C. Digiovanni, S. Hares [et al.] // J. Am. Acad. Orthop. Surg. - 2012. - Vol. 20. - P. 310-319.

6. Drew B. Application of current hemorrhage control techniquesfor backcountry care: part one, tourniquets and hemorrhage control adjuncts / B. Drew, B. Bennett, L. Littlejohn //Wilderness and Environmental Medicine.-2015.No. 26. - P. 236-245.

7. Молекулярные механизмы развития и адресная терапия синдрома ишемии-реперфузии / О. А. Гребенчиков, В. В. Дихванцев, Е. Ю. Плотников [и др.] // Актуальные вопросы анестезиологии и реаниматологии. 2014. - № 3. - C. 59-67.

8. Blaisdell F. W. The pathophysiology of skeletal musculeishemia and the reperfusion syndrome: a rewiew / F. W. Blaisdell // Cardiovasc. Surg. - 2002. - Vol. 10. - P. 620-630.

9. Ying W. Oxidative stress and NAD+ in ischemic brain injury: current advances and future perspectives / W. Ying, Z.-G. Xiong // Current Medical Chemistry. - 2010. - Vol. 17, No. 20. - P. 2152-2158.

10. Горобець Н. М. Нові стратегічні підходи до корекції ендотеліальної дисфункції / Н. М. Горобець // Ліки України. - 2015. - № 2. - С. 20-24.

11. Зятковська О. Я. Патогенетична роль перекисного окислення ліпідів і антиоксидантного захисту в умовах комбінованої травми / О. Я. Зятковська // Здобутки клінічної і експериментальної медицини. - 2010. № 2 (13). - С. 50-55.

\section{REFERENS}

1. Pokrovskiy, A.V. \& Bokeriya, L.A. (2013). Natsionalnye rekomendatsii po vedeniyu patsiyentov s zabolevaniyami arteriy nizhnikh konechnostey [National guidelines for the management of patients with diseases of the lower limb arteries]. Moscow [in Russian].

2. Gubka, V.O. (2015). Rezultaty likuvannia khvorykh iz hostroiu arterialnoiu ischemiieiu kintsivok [Results of treatment of patients with acute arterial limb ischemia]. Patolohiia - Pathology, 2, (34), 55-58 [in Ukrainian].

3. Gavrilenko, A.V. \& Shabaltas, E.D. (2003). Sostoyanie mikrotsirkulyatsii pri reperfuzionnom sindrome posle rekonstruktivnykh operatsiy na sosudakh nizhnikh konechnostey [The state of microcirculation in reperfusion syndrome after reconstructive operations on the vessels of the lower extremities]. Khirurgiya - Surgery, 2, 62 [in Russian].

4. Henyk, S.M., \& Symchych, A.V. (2016). Reperfuziinyi syndrom pislia revaskuliaryzatsii ishemii nyzhnikh kintsivok [Reperfusion syndrome after revascularization of the ischemic lower limbs]. Sertse i sudyny - Heart and Vessels, 3, 104108 [in Ukrainian].

5. Fitzgibbons, P.G. , Digiovanni, C. \& Hares, S. (2012). Safe tourniquet use: a review of the evidence. Journal of the American Academy of Orthopaedic Surgeons, 20, 310-319.

6. Drew, B., Bennett, B. \& Littlejohn, L. (2015). Application of current hemorrhage control techniquesfor backcountry care: part one, tourniquets and hemorrhage control adjuncts. Wilderness and Environmental Medicine, 26, 236245.
12. Козак Д. В. Динаміка показників антиоксидантного захисту у відповідь на політравму / Д. В. Козак // Шпитальна хірургія. - 2012. - № 3 (59). - С. 60-64.

13. Мальченко О. А. Изменение активности неспецифических протеиназ и их ингибиторов в мышечной ткани крыс при экспериментальном реперфузионном синдроме / О. А. Мальченко, Л. В. Анисимова, А. В. Кубышкин // Вісник морфології. - 2014. - № 2, Т. 20. C. 388-391.

14. Гаврилов В. Б. Спектрофотометрическое определение гидроперекисей в плазме крови / В. Б. Гаврилов, М. И. Мишкорудная // Ла6. Дело. - 1983. - № 3. С. 34-37.

15. Коробейникова Э. Н. Модификация определения продуктов ПОЛ в реакции с тиобарбитуровой кислотой / Э. Н. Коробейникова // Лаб. дело. -1989. - № 7.C. 8-10.

16. Метод определения активности каталазы / М. А. Королюк, Л. И. Иванова, И. Г. Майорова [и др.] // Лаб. дело. - 1988. - № 1. - С. 16-18.

17. Чевари С. Роль супероксидредуктазы в окислительных процессах клетки и метод определения ее в биологическом материале / С. Чевари, И. Чаба, Й. Секей // Лаб. дело. - 1985. - № 11. - С. 678-681.

18. Мерлєв Д. І. Роль морфо-функціональних змін нирок в патогенезі ранніх проявів краніо-скелетної травми: дис. канд. мед. наук : спец. 14.03.04 “Патологічна фізіологія" / Д. І. Мерлєв. - Тернопіль, 2015. - 195 с.

7. Grebenchikov, O.A., Dihvantsev, V.V. \& Plotnikov, E. Yu. (2014). Molekulyarnye mekhanizmy razvitiya i adresnaya terapiya sindroma ishemii-reperfuzii [Molecular mechanisms of development and address therapy of ischemia-reperfusion syndrome]. Aktualnye voprosy anesteziologii i reanimatologii - Actual Questions of Anesthesiology and Reanimatology, 3, 59-67 [in Russian].

8. Blaisdell, F.W. (2002). The pathophysiology of skeletal musculeishemia and the reperfusion syndrome: a rewiew. Cardiovascular Surgery, 10, 620-630.

9. Ying, W. \& Xiong, Z.-G. (2010). Oxidative stress and $\mathrm{NAD+}$ in ischemic brain injury: current advances and future perspectives. Current Medical Chemistry, 20, 21522158.

10. Horobets, N. M. (2015). Novi stratehichni pidkhody do korektsii endotelialnoi dysfunktsii [New strategic approaches to correction of endothelial dysfunction ]. Liky Ukrainy - Medicine of Ukraine, 2, 20-24 [in Ukrainian].

11. Ziatkovska, O.Ya. (2010). Patohenetychna rol perekysnoho okyslennia lipidiv i antyoksydantnoho zakhystu v umovakh kombinovanoi travmy [Pathogenetic role of lipid peroxidation and antioxidant protection in combined traumatic conditions]. Zdobutky klinichnoi i eksperymentalnoi medytsyny-Achievements of Clinical and Experimental Medicine, 2 (13), 50-55 [in Ukrainian].

12. Kozak, D.V. (2012). Dynamika pokaznykiv antyoksydantnoho zakhystu u vidpovid na politravmu [Dynamics of indicators of antioxidant defense in response to polytrau- 
Огляди літератури, оригінальні дослідження, погляд на проблему, ювілеї ma]. Shpytalna khirurhiia - Hospital Surgery, 3 (59), 60-64 [in Ukrainian].

13. Malchenko, O.A., Anisimova, L.V., \& Kubyshkin, A.V. (2014). Izmenenie aktivnosti nespecificheskih proteinaz i ikh ingibitorov v myshechnoy tkani krys pri eksperimentalnom reperfuzionnom syndrome [Changes activity of nonspecific proteinases and their inhibitors in rats muscule tissue with experimental reperfusion syndrome]. Visnyk morfolohii Reports of Morphology 2, (20), 388-391 [in Russian].

14. Gavrilov, V.B. \& Mishkorudnaya, E.N. (1983). Spektrofotometricheskoe opredelenie gidroperekisey $v$ plazme krovi [Spectrophotometric determination of hydroperoxides in blood plasma]. Laboratornoye delo-Laboratory work, 3, 34-37 [in Russian].

15. Korobeynikova, E.N. (1989). Modifikatsiya opredeleniya produktov POL v reaktsii s tiobarbiturovoy kislotoy [Modification of the definition of LPO products in reaction

with thiobarbituric acid]. Laboratornoye delo - Laboratory Work, 7, 8-10 [in Russian].

16. Korolyuk, M.A., Ivanova, L.I. \& Mayorova, I.G. (1988). Metod opredeleniya aktivnosti katalasyi [Method for determination of catalase activity]. Laboratornoye delo - Laboratory work, 1, 16-18 [in Russian].

17. Chevary, S., Chaba, I. \& Sekei, Y. (1985). Rol superoksydreduktazy $v$ okyslytelnykh protsessakh kletky i metod opredelenyia ee $v$ biologicheskom materiale [The role of superoxide reductase in the oxidative processes of the cell and the method for determining it in biological material]. Laboratornoye delo - Laboratory Work, 11, 678-681 [in Russian].

18. Merliev, D. I. (2015). Rol morfo-funktsionalnykh zmin nyrok v patohenezi rannikh proiaviv kranio-skeletnoi travmy [The role of morpho-functional renal changes in the pathogenesis of early manifestations of cranio-skeletal trauma]. Candidate's thesis. Ternopil [in Ukrainian].

\title{
ДИНАМИКА ПОКАЗАТЕЛЕЙ ПЕРЕКИСНОГО ОКИСЛЕНИЯ ЛИПИДОВ И АНТИОКСИДАНТНОЙ ЗАЩИТЫ В МЫШЕЧНОЙ ТКАНИ ЗАДНИХ КОНЕЧНОСТЕЙ КРЫС ПРИ РАЗВИТИИ ИШЕМИЧЕСКИ-РЕПЕРФУЗИОННОГО СИНДРОМА (ЭКСПЕРИМЕНТАЛЬНОЕ ИССЛЕДОВАНИЕ)
}

\author{
๑А. Т. Телевяк
}

\author{
ГВУЗ «Тернопольский государственный медицинский университет имени И. Я. Горбачевского»
}

РЕЗЮМЕ. Острая ишемия конечности возникает в результате внезапного снижения ее перфузии, обычно возникающей при обтурации просвета крупных артерий вследствие острого тромбоза или эмболии, а также нарушения проходимости сосудов, вызванного их травмами или сжатием (включая наложение кровоостанавливающих турникетов). В случае восстановления кровоснабжения ранее ишемизированных тканей возникает ишемически-реперфузионный синдром, при котором одним из главных патогенетических звеньев альтерации тканей является активация перекисного окисления липидов.

Цель исследования - провести сравнительный анализ показателей перекисного окисления липидов и антиоксидантной защиты в гомогенате мышечной ткани задних конечностей крыс в разные периоды развития ишемически-реперфузионного синдрома.

Материалы и методы. Проведено определение содержания диеновых конъюгат, триенових конъюгат, ТБКактивных продуктов, супероксиддисмутазы и каталазы в гомогенате мышечной ткани 30 крыс в условиях экспериментальной острой ишемии. Острую ишемию вызывали путем наложения резиновых жгутов SWAT (StretchWrap-And-Tuck) на задние конечности животных продолжительностью 2 часа. Количественные показатели обрабатывали статистически.

Результаты. Экспериментально установлено, что максимальный рост содержания диеновых и триенових конъюгат в поврежденной мышечной ткани животных происходил в раннем постишемическом периоде на 2-ой час реперфузии со снижением на 1-е и 7-е сутки и возвратом к уровню показателей контрольной группы в позднем постишемическом периоде на 14-е сутки. Возрастание содержания ТБК-активных продуктов в мышечной ткани происходило в первых трех группах крыс и достигало максимума в третьей группе (реперфузия 1 сутки), после чего снижалось у животных позднего реперфузионного периода, достигнув в последней группе значений, близких к показателям контрольной группы.

Активность супероксиддисмутазы и каталазы постепенно возрастала в раннем постишемическом периоде и достигла максимума на 7-е сутки ишемически-реперфузионного синдрома, после чего на 14-е сутки показатели вернулись к уровню значений группы контроля. Сильная положительная корреляционная связь между показателями содержания супероксиддисмутазы и каталазы $(+0,99)$ указывала на аналогичную динамику изменений указанных показателей. Во всех экспериментальных группах крыс в мышечном гомогенате отмечалось снижение антиоксидантно-прооксидантного индекса, которое было наиболее выраженным на 1-е сутки ишемии-реперфузии.

Выводы. Во всех исследуемых группах животных развивался ишемически-реперфузионный синдром с активацией перекисного окисления липидов и антиоксидантной защиты. Перекисное окисление липидов нарастало в мышечной ткани, начиная с 1-го часа реперфузии, и достигало максимума на 1-е сутки, после чего большинство показателей постепенно возвращались к значениям контрольной группы на 7-е и 14-е сутки реперфузии. Активность ферментов антиоксидантной защиты также постепенно возрастала и достигла в мышечной ткани максиму- 
Огляди літератури, оригінальні дослідження, погляд на проблему, ювілеї

ма на 7-е сутки, а на 14-е сутки произошло возвращение показателей антиоксидантной защиты к уровню значений группы контроля. Рост активности супероксиддисмутазы и каталазы свидетельствует об активации компенсаторных механизмов антиоксидантной защиты в ишемизированной мышечной ткани, а их относительно невысокое возрастание может указывать на субкомпенсированный уровень развития этих механизмов.

Уменьшение показателя антиоксидантно-прооксидантного индекса в мышечной ткани было наиболее выраженным на 1-е сутки реперфузии, после чего индекс постепенно возрастал. О противоположных тенденциях в динамике изменений содержания про- и антиоксидантов в гомогенате ишемизированной мышечной ткани свидетельствует и обратная корреляционная связь средней силы между продуктами перекисного окисления липидов (диеновые и триеновые конъюгаты) и ферментами антиоксидантной защиты (супероксиддисмутаза и каталаза).

КЛЮчЕВЫЕ СЛОВА: острая ишемия; мышечная ткань; ишемически-реперфузионный синдром; перекисное окисление липидов; антиоксидантная защита.

\section{THE DYNAMIC OF INDICATORS OF LIPID PEROXIDATION AND ANTIOXIDANT PROTECTION IN MUSCLE TISSUE OF THE HIND LIMBS OF THE RATS IN DEVELOPMENT OF THE ISCHEMIC-REPERFUSION SYNDROME (EXPERIMENTAL STUDY)}

\section{Horbachevsky Ternopil State Medical University}

๑A. T. Televiak

SUMMARY. Acute limb ischemia occurs as a result of sudden decrease in its perfusion, which usually occurs during the obturation of the lumen of large arteries due to acute thrombosis or embolism either impaired of vascular patency caused by trauma or compression (including the application of hemostatic tourniquets). In case of restoration of blood supply to the previously ischemic tissues arises an ischemic-reperfusion injury, in which one of the main pathogenetic links of the tissue alteration is the activation of lipid peroxidation.

The aim of the study - to make the comparative analysis of lipid peroxidation and antioxidant protection in homogenat of muscle tissue the hind limbs of rats in different periods of ischemic-reperfusion syndrome.

Material and Methods. The determination of the content of conjugated dienes, conjugated trienes, TBA-active products, superoxide dismutase and catalase in the muscle tissue homogenate of 30 rats under experimental acute ischemia were performed. Acute ischemia was caused by the application of SWAT (Stretch-Wrap-And-Tuck) rubber bands on the hind limbs of the animals for 2 hours. Quantitative indicators were processed statistically.

Results and Discussion. It has been experimentally determined that the maximum increase in the content of diene and triene conjugates in damaged muscle tissue of animals occurred in the early postischemic period at $2 \mathrm{nd}$ hour of reperfusion with a decrease on the 1 st and 7 th days and return to the level of the indicators of the control group in late postischemic period on the 14th day. The increase of TBA-active products in muscle tissue occurred in the first three groups of rats and peaked in 3rd group (reperfusion 1 day), and then decreased in animals of the late reperfusion period, reaching in the last group the values close to control group values. The activity of superoxide dismutase and catalase gradually increased in the early postischemic period and reached the maximum at the 7th day of ischemic-reperfusion syndrome, after which the indicators returned to the level of control group values on the 14th day. A strong positive correlation between the content of superoxide dismutase and catalase $(+0.99)$ indicated a similar dynamics of changes in thise indicators. In all experimental groups of rats in the muscle homogenate there was a decrease of antioxidantprooxidant index, which was most pronounced at 1st day of ischemia-reperfusion.

Conclusions. In all studied groups of animals, an ischemic-reperfusion syndrome with activation of lipid peroxidation and antioxidant defense was developed. The lipid peroxidation increased in muscle tissue from 1 hour of reperfusion and reached a maximum of 1st day, after which most indicators gradually returned to values of control group on the 7 th and 14th days of reperfusion. The activity of antioxidant protection enzymes also gradually increased and reached the maximum in muscle tissue at the 7th day, and on the 14th day, the return of antioxidant protection values to the level of control group was observed. The increase of superoxide dismutase and catalase activity indicates the activation of compensatory mechanisms of antioxidant protection in ischemic muscle tissue, and their relatively low increase may indicate a subcompensated level of development of these mechanisms.

The decrease in the antioxidant-prooxidant index in the muscle tissue was maximal on 1st day of reperfusion, after which the index gradually increased. The opposite trend in the dynamics of changes in the content of pro- and antioxidants in the homogenate of ischemic muscle tissue is also confirmed by the inverse correlation the average strength between the products of the lipid peroxidation (diene and trienine conjugates) and antioxidant protection enzymes (superoxide dismutase and catalase).

KEY WORDS: acute ischemia; muscle tissue; ischemic-reperfusion syndrome; lipid peroxidation; antioxidant protection.

Отримано 12.08.2018 